\title{
A MODEL FOR THE IDENTIFICATION OF AREAS FAVOURABLE FOR THE DEVELOPMENT OF TOURISM: A CASE STUDY OF THE $\square$ UMAVA MTS. AND SOUTH BOHEMIA TOURIST REGIONS (CZECH REPUBLIC)
}

\author{
Josef NAVRÁTIL, Kamil PÍCHA, Stanislav MARTINÁT, Jaroslav KNOTEK, Tomáš KUČERA, \\ Zuzana BALOUNOVÁ, Vivian L. WHITE BARAVALLE GILLIAM, Roman ŠVEC, Josef RAJCHARD
}

\begin{abstract}
A basis for the identification of potential tourist development areas was defined as a combined use of the model of area load by visitors, the territorially-located database of tourist attractions, and the perception of their attractiveness by visitors. A distinctive inequality was identified in the area load and the distribution of tourist attractions. The areas of development were determined on the basis of a difference between the relative attendance and the relative attractiveness of the partial territorial units of a regular hexagonal network, sized approximately $3 \mathrm{~km}^{2}$, with a concurrent requirement of above-average total attractiveness.
\end{abstract}

\section{Shrnutí}

Model identifikace rozvojových oblastí cestovního ruchu: Turistické regony Šumava a Jižní Čechy (Česká republika)

Základem pro identifikaci potenciálních rozvojových oblastí se stalo kombinované využití modelu zatíženosti oblasti návštěvností, územně lokalizované databáze atraktivit cestovního ruchu a percepce míry jejich atraktivnosti návštěvníky oblasti. Identifikována byla výrazná nerovnoměrnost $v$ zatížení oblasti cestovním ruchem a nerovnomèrnosti v rozmístění atraktivit cestovního ruchu. Rozvojové oblasti byly určeny na základě rozdílu relativní návštěvnosti a relativní atraktivity $v$ dílčích územních jednotkách pravidelné šestiúhelníkové sítě, jejichž přibližná rozloha je $3 \mathrm{~km}^{2}$, a při současně splněném požadavku na nadprüměrnou hodnotu celkové atraktivnosti.

Keywords: GIS, tourism, development, model, Šumava Mts. and South Bohemia tourist regions, Czech Republic

\section{Introduction}

Regional development policies are anchored in paradigms of particular economic and geographical theories, which are expressed in the diversified scale of regional development theories (Dawkins, 2003) and whose application should achieve the objectives of regional (or local) competitiveness (Kitson, Martin and Tyler, 2004). Support for the activities of tourism are important elements of regional development policies in the long term. Those policies dwell on the parallel evolution of both development and tourism theories since World War II (Telfer, 2002a). The realization of tourist activities manifests itself in the economic benefits for the visited area (Dwyer, Forsyth and Dwyer, 2010) through the transfer of income and investments from wealthier and more developed territories to the poorer and less developed ones
(Sharpley, 2002). The main benefits come from the visitors' expenses in the tourist destinations, as well as investment in tourism infrastructure by businesses coming from the areas that generate tourists.

There are, however, both positive and negative impacts (Williams, 1998). As an important sector of the economy (Dwyer et al., 2010), tourism influences a wide spectrum of development issues in the destination regions. Such issues are, among others, the economy (Mihalič, 2002), as well as socio-cultural matters (Hashimoto, 2002) or community matters (Timothy, 2002). For these reasons, tourism is one of the important elements of regional development policies in various contexts, be it sustainable life in rural areas, the revitalization of towns, or support to generally poorer areas or island economies (Telfer, 2002b). The assertion that tourist 
activities could be 'friendly' to their environments came quite recently (particularly in the context of physical impacts of tourism on the environment: Hall and Lew, 2009). Overall, the purpose is to let the losses due to the existence of tourism not exceed the generated benefits (Christofakis, 2010).

Although regional development studies often place emphasis on the economic aspects of the topic (Ray, 2008), this subject has also many other approaches that are based primarily in geography, psychology, sociology, environmental studies and the like. These problems of tourism have a highly multidisciplinary character (Williams, 1998). Although it is usually not mentioned in regional development studies, the visitor is a key element of the development. The visitor is the one who realizes the expenses in those destination areas and for whom the tourism infrastructure is built (Goeldner and Ritchie, 2009). Hence, attendance in an area (its quantity and quality) is fundamental for the realization of the development potential of tourism within the destination area. All of the above-mentioned factors led the authors to opt for the identification of tourism development areas (in its spatial meaning) as the aim of this paper.

The chosen objective is certainly not new in research on the problems of the spatial and development aspects of tourism (Benthien, 1997). It is one of the key problems to be resolved by tourism geography (Williams, 1998), and it is currently further developed in this context (Hall and Page, 2009) and thus constitutes a part of the main paradigm (Gibson, 2008).

This paper is based on a combination of varied approaches to the assessment of attractiveness of core resources (Ritchie and Crouch, 2003). Unlike similar studies that emanate from our cultural environment, the core of selected methods is not concerned with the typological-spatial analysis (e.g. Vystoupil et al., 2006) but rather in the analysis of the visitor's relationship to those resources. Even the analysis we have chosen is not exceptional (e.g. Pompurová, 2011), but other research is usually not directly linked with concrete spatial elements. They are commonly related to products supplied by enterprises or otherwise reset from expert estimations (Bína, 2002; Vepřek, 2002; Švec et al., 2012). The purpose of the present study is to extend the abovementioned current knowledge and research experience.

\section{Methods}

Potential areas of development were identified within the model territory of the tourist regions of South Bohemia and the Šumava Mountains (Cetkovský, Klusáček, Martinát and Zapletalová, 2007). The model of attendance was employed to serve as an initial model of the load of the area (Navrátil, Švec, Pícha, and Doležalová, 2012: for details about the methods, see p. 52-53). For further calculations in this paper, we used the layers of GIS with the data on total model attendance of partial spatial units of the regular hexagonal network, according to input data for the year 2010 .

The model of the attractiveness of an area proceeds from the spatially located database of potential attractions that were identified in literature devoted to the issues of tourism geography (Kušen, 2010; Mariot, 1983; Navrátil and Navrátilová, 2011; Ritchie and Crouch, 2003; Vystoupil et al., 2006). The database comprises potential attractions, which are parts of permanent structures, i.e. those which cannot be moved or newly built, according to the upto-date demand of tourists (Gunn, 1997). In particular, elements of physiognomy, culture and history (in the meaning of Ritchie and Crouch, 2003) are considered: in total, 69 types of attractions.

The following elements were used from the category of "physiognomy":

- land use: the polygonal layer for the whole surveyed territory, divided according to land use types (Löw and Novák, 2008) - agricultural, forestagricultural, forest, pond and urbanized landscape;

- landscape types: the polygonal layer of the whole surveyed territory, divided according to the type of relief(Löw and Novák, 2008)-landscapes of hilly areas and uplands of Hercynicum, landscapes of flatlands, landscape of broad floodplain meadows (Fig. 1 - see cover p. 2), landscape without differentiated relief towns; landscapes of highlands, landscape of highly situated plateaus, karst landscapes, landscapes of distinctive hillsides and rocky mountain ridges, landscape of cirques, landscape of carved valleys and landscapes of volcanic mounds and cones;

- attractions of living nature - the polygonal layer; a subject of protection was identified within the bounds of small-area protected territories (AOPK ČR, 2011) and it was encoded to the three types of attractiveness that are included in the object of protection (Fig. 2 - see cover p. 2) - forest, peatbog, meadow, plant and animal. With regard to the source of data, the rocks were supplemented; and

- attractions of inanimate nature: the point layer with points of attractions: caves located on the basis of the open-access database of the United Evidence of the Speleological Objects of the Agency for Nature Conservation and Landscape Protection of the Czech Republic (AOPK ČR, 2012), springs and sources were localized on the basis of the tourist map of the service www.mapy.cz (SHOCart, 2012), 
mineral water springs were located based on the sources of literature (Kř́iž, 1985), and waterfalls were located according to the tourist maps of the Czech Tourist Club 1:50 000.

The following elements were used from the category of "culture and history":

- historical and cultural attractions: the point layer with points located primarily according to the tourist maps of the Czech Tourist Club 1:50 000; the following elements were recorded into the database - church, monastery, chapel, Jewish monument (only those attractions that were mentioned in the text part of the tourist maps), tower house (Fig. 3 - see cover p. 4), castle, remains of fortresses and fortified settlements, ruins of castle or other monuments, memorial of an important person, memorial of an important event, Calvary chapel, Calvary cross, conciliation cross, historically important cemetery, museum, open-air museum, gallery, point of an important historical event, place where an important historic person was living and/or creating, important (usually geographically or historically) border stone, theatre, observation and viewpoint;

- historical and cultural attractions: the polygonal layer including abandoned and dilapidated villages (Fig. 4 - see cover p. 4), located on the basis of the map from the second military mapping; monuments of popular architecture localized using the data of the National Heritage Institute (NPÚ, 2012) - the border of village monument reservations, borders of the village monument zones and proposals of the village monument zones within their residential area were used; the database was also supplemented (under the notion "town monument reservation"; according to the same materials) town monument reservations and zones within those borders as they were declared or within the border of the historical core of the town (in the case where there is only a proposal of such declaration); and

- technical monuments: the point layer created according to the information stated in the edition of technical monuments of the publishing house Libri and supplemented with information according to the tourist maps of the Czech Tourist Club 1:50 000 - historical factories, historical mines and panning sites, rural workrooms and storehouses, water mills and iron-mills, historical transport equipment, water tanks and waterworks towers (usually from the second half of the $19^{\text {th }}$ century or the first half of $20^{\text {th }}$ century) and water dams. The line layer of the line fortification of the Czechoslovak Republic was further created based on information from the server ropiky.net (WWW.
ROPIKY.NET, 1999-2012) that were validated by information originating from the tourist maps of the Czech Tourist Club 1:50 000.

The database was completed with recreational attractions that are dependent, first of all, directly on the natural environment:

- public outdoor swimming pools and bathing places: the points were located based on the information published in the Digital Territory Model (DTM) 1:25 000, supplemented with information from the tourist maps of the Czech Tourist Club 1:50 000;

- tennis courts: the points were located based on the information mentioned in the DTM 1:25 000;

- places suitable for paddling: the line created according to the information mentioned in the Atlas of Tourism in the Czech Republic (Vystoupil et al., 2006) and the Atlas for Leisure Time (Economia, 2002);

- horse riding: the points of the location of riding schools were done according to the sources available via the Internet network;

- downhill skiing: the polygons were created according to the information mentioned in the tourist maps of the Czech Tourist Club 1:50 000 and in the DTM 1:25 000;

- golf: the polygons were created according to the information mentioned in the tourist maps of the Czech Tourist Club 1:50 000 and in the DTM 1:25 000 and completed with sources available via the Internet network;

- mountain climbing: the points of location of the registered places were determined according to the sources available via the Internet network;

- sport fishing: the line of the fisheries of the Czech Fishing Union (ČRS, 2003) and private fisheries (Navrátil, 2004);

- spas: the polygons were located according to the information in DTM 1:25 000;

- zoological garden: the polygons were located according to sources available via the Internet network;

- botanical garden and arboretum: the polygons were located according to the publication Botanical Gardens and Arboreta of the Czech Republic (Chytrá, Hanzelka, and Kacerovský, 2010); and

- astronomical observatories and planetariums: the points of location according to the sources available via the Internet network.

First of all, the characteristics of the distribution of the set of identified attractions were assessed. That was carried out using the main tools of frequency assessment of differences and regularities in the distribution. With regard to the large extent of the input data, the set of 
the attractions was assessed as a whole, not as partial separate types of attractions. Afterwards, regularity in the distribution was established by means of Nearest Neighbour Analysis (Aplin, 1983). Values of the $R$ statistics and Z-scores were computed by means of the software Quantum GIS 1.7.1 (Athan et al., 2011).

The attractiveness of the territory was assessed in identical artificial spatial units, identified as those used previously in the model of attendance of the surveyed territory (Navrátil et al., 2012). The attractiveness of the territory was calculated on the basis of the sum of the attractiveness of the above-mentioned elements in the partially determined territorial units. So, before the proper calculation was made, it was necessary to convert the polygonal and line layers to the points. The polygons and lines were first interlaid by the layer of partial territorial units and subsequently followed a calculation of the centroids of the newly emerged polygons and lines. The occurrence of a point from the original polygon or the line in the polygon of the partial territorial unit, would then require the addition of the attractiveness of the respective type of point to the total attractiveness of the polygon of the concerned partial territorial unit. The exception was represented by the layers of land use and the types of landscape, which cover the whole area of the surveyed territory: here it was necessary to determine the share of particular types on the total area of partial determined territorial units, before both the rate of attractiveness was taken into account and the calculation of centroids was done. Then the attractiveness of the partial sections was fixed as a product of the share of the given land use type on the total area of the partial territorial unit and the rate of attractiveness of the respective type, which was determined by the hereinafter described procedure.

Our previous research on the surveyed territories (Navrátil, Pícha and Hřebcová, 2010; Navrátil, Pícha, Rajchard and Navrátilová, 2011; Navrátil et al., 2013) showed that the usual assessment of the simple spatial distribution cannot be used for the identification of potential development areas. The partial segments of demand differ in attractiveness. For this reason it was necessary to complete the database of the perception of attractiveness by a wider spectrum of visitors. The segments of demand were identified based on the combination of two approaches - interrogating real visitors about the attractions, and interrogating within the model segments. A basis for the identification of the segments became the intensity of running recreational activities during the spending of leisure time by people outside their permanent address (Navrátil et al., 2010). The identical tool was used for testing the influence of the partial segments of demand on the perception of attractiveness (Navrátil et al., 2013).
The respondents were surveyed at 60 attractions in the tourist regions of South Bohemia and the Šumava Mountains in the years 2009-2011. The authors had a database of 3,776 completed questionnaires at their disposal (Navrátil, unpublished data). The selection of the respondents was identical to that published in Navrátil, Pícha, and Navrátilová (2012) and the set of locations was extended (compared to the previously-cited article) with those types of attractions where the attractiveness consisted of elements from culture, history, and recreation. The self-same questionnaire was presented to students selected in compliance with methods used in Navrátil et al. (2013). 396 questionnaires were filled in by those students (return rate of questionnaires was $61 \%$ ). The students were likewise asked about the rate of attractiveness of partial attractions from the abovementioned list. The Q-sort Method was used with regard to the number of the observed attractions, as that method allowed the researchers to assess a large number of elements (Doody, Kearney, Barry, Moles, and O'Regan, 2009), where the load on respondents is relatively low, which prevents the negative effect influence of the previous answers (Barry and Proops, 1999), which is, on the contrary, the case of scales or paired comparisons. An eleven-column scheme was used. The assigned task was worded as follows: "Please, classify the following elements of attractiveness of the tourist areas according to the importance you attribute to the particular elements when choosing the place to travel there". The +5 in this Q-sort corresponds to the statement "It has a crucial importance for my selection of the place to travel to" and the -5 "It has absolutely no importance for my selection of the place to travel to". The number of attractions for the particular columns was selected to be close to the normal distribution (1-24-7-12-17-12-7-4-2-1).

The segments of demand were identified by means of cluster analysis (Ward's method, Euclidean distance) of answers on the scale of the degree of participation in the partial recreational activities in all questionnaires on the level of 50\% loss of credibility (Real, Arce, and Sabucedo, 2000). The available hardware did not allow processing of all obtained responses; hence, a randomly selected 2,500 questionnaires were involved in the computation. Besides the proper identification of the segments of demand, the share of particular segments of demand of all visitors in the surveyed tourist regions should be determined.

Those questionnaires filled in by students were further selected from the identified clusters and students' answers concerning the degree of attractiveness were used to calculate the average value of attractiveness of the given attraction for the respective segment of 
demand. With regard to the methods of data collection, it was necessary to convert the scale of assessing the attractions to positive values and consequently to transform it exponentially before other calculations. The final value of attractiveness for each segment of demand was expressed relatively, as a part of attractiveness of the partial attractions on the maximal value of the achieved attractiveness of the most attractive item. Those values were assigned to the given type of attraction in the database, and this was defined separately for each segment of demand.

The model of the total attractiveness of the territory was created for particular segments of demand (as a sum of attractiveness for a given segment of demand). Based on the attractiveness for the partial segments of demand and their known representation in the demand for tourism in the surveyed territory, it was possible to create a final model of the complex attractiveness of the territory.

All computations and analysis of the questionnaires concerning attractiveness were done using the STATISTICA 10.0 software(StatSoft,2011). The results were visualized in the environment of ArcView 3.1 For visualization, the quartiles calculated from all values achieved in the set of all types of attractions were used in all cases of models of attractiveness of particular groups of attractions. In the case of the attractiveness of the territory according to particular segments of demand, a scale was similarly created based on quartiles of all the attractiveness values of all segments of demand. The resulting cartograms are quantitatively comparable by visualization.

The assessment of the load of the territory is derived from the comparison of the values of model attendance rate and model attractiveness in each hexagon. The data of both the model of the attendance rate and the model of attractiveness were firstly standardized, and then the differences were investigated. The resulting values were again visualized in ArcView 3.1 using the quartiles. The areas with positive values show a surplus of attractiveness compared to the median of all the surveyed area and then a relatively unutilized attractiveness of tourism development. However, it is not possible to label these areas as "developing". It is possible to define this only in those territories which at the same time show above-average values of total attractiveness.

\section{Results and discussion}

The model of tourist load in the surveyed area identified three tourism zones (Fig. 5). The largest area is situated in the south-east of the territory and comprises areas from the border of the Třeboň area and the Czech Canada on the north-east, over the central Třeboň area with centre in Třeboň, and in the locations of Staňkovský-Hejtman, Hluboká-České Budějovice and Český Krumlov, up to the Lipno Dam area on the south-west. The second tourism zone is the western Šumava Mountains with centres in the area of Železná Ruda and alongside the Vydra River. The third tourism zone in the surveyed area is the area of Písek with the Orlík Dam Lake and the town of Tábor. There is some manifestation of a border effect in the model. However, its importance is not strong as the above-average visited areas appear in many cases right at the borders of the territory (the Šumava Mountains, the Třeboň area and the Orlík Dam Lake). We can then consider the model to be valid as it shows conformity in the distribution with empirical experience gained directly in the field.

After all adjustments of line and polygonal vector layers of the attractions to the points assignable unambiguously to the particular areas of the regular hexagonal network, the databases include 27,299 items.

Several relationships in the data set are obvious with regard to spatial distribution (Fig. 6). First of all, the spatial accumulation of attractions in specific areas stands out. These are especially the towns, which is not at all surprising. The reason for this is a relatively high number of the types of attractions from the culturehistorical category, and the majority of these attractions is linked, above all, with the urbanized areas. Another evident element is the accumulation of attractions along water courses, which is partially caused by their originally line character and also by the fact that several types of the observed attractions are closely related to water: paddling sections and fisheries. However, this should also be linked to the appearance of change of relief type that is usually different from its surroundings along larger watercourses. The last noticeable element is the accumulation of the types of attractions near the edge of mountains, where the character of the relief changes, similar to the case of the watercourses, and where the character of land use often changes as well. So an overall impression is that of the entwining of the types of attractions appertaining to both mountains and lowlands. The Nearest Neighbour Analysis proved the important tendency towards the creation of spatial clusters of attractions, as the R-statistic achieves 0.214 with a value of the Z-score $=-248.6$.

The degree of attractiveness of the particular surveyed tourist attractions was investigated using the method of interrogating real tourists in the specified territory and the method of the model segments of demand. Before making the proper calculations of both partial and total attractiveness values, it was necessary to identify those 


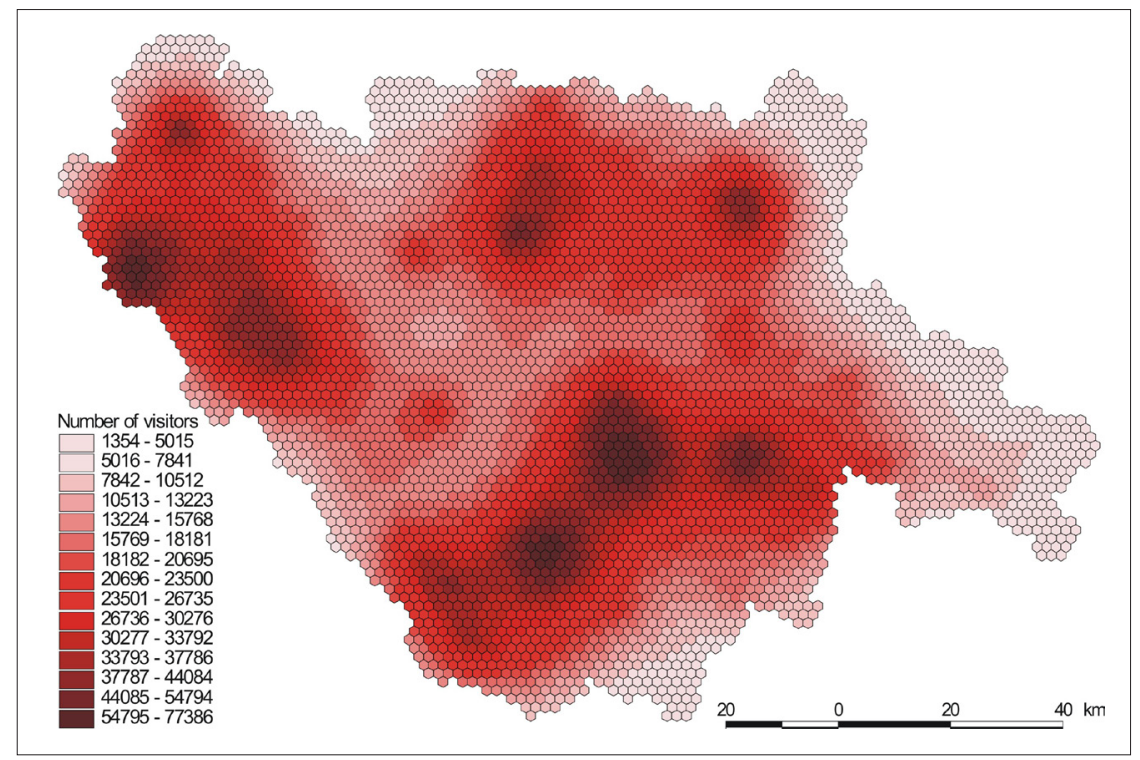

Fig. 5: The model of the number of visitors in particular locations of the tourist regions South Bohemia and the Šumava Mountains

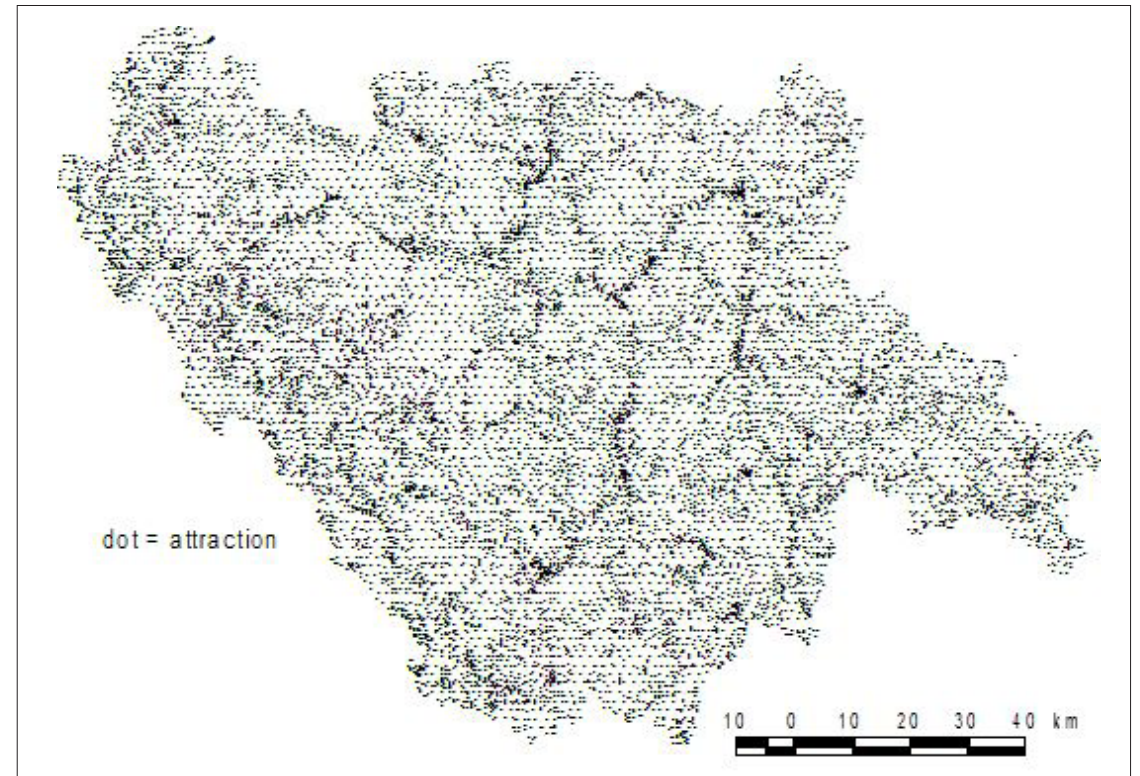

Fig. 6: The distribution of all attractions included in the database, $N=27,299$

segments of demand that were determined on the basis of behavioural segmentation criteria (Moutinho, 2000). The cluster analysis of their responses regarding the degree of participation in the partial recreational activities (linked with travelling) helped to identify four main segments of demand (the share of the total number of respondents is indicated in brackets):

- modern outdoor tourism oriented primarily to bicycle touring and entertainment-linked with a visit to the "natural" environment (13.65\%);

- traditional tourism oriented to the stay in nature and visit to a historical monument, refusing modern elements represented by bicycle touring (31.46\%);

- rather passive and non-engaged tourism with predominant importance consisting of easily accessible destinations (26.44\%); and
- hotel-based tourism oriented more towards entertainment and recreational activities (28.45\%).

The above-mentioned segments of demand correspond to the structure identified in previous studies (Navrátil, 2008; Navrátil et al., 2010). From the marketing point of view, they could seem to be too rough and simplistically oriented (Kotler and Keller, 2007). However, the objective was not to describe in detail the segments at the micro-level, but to identify major ways of behaving in relation to the attractions from the group of location preconditions for tourism (Mariot, 1983). From that point of view, the classification of four groups is optimal and a huge number of differentiating activities was identified in the spectrum of segmentation questions (Tab. 1). 


\begin{tabular}{|l|c|c|c|c|c|c|c|c|c|c|c|c|}
\hline & \multicolumn{3}{|c|}{$\begin{array}{c}\text { modern outdoor } \\
\text { tourism }\end{array}$} & \multicolumn{2}{c|}{$\begin{array}{c}\text { traditional outdoor } \\
\text { tourism }\end{array}$} & \multicolumn{2}{c|}{$\begin{array}{c}\text { non-engaged } \\
\text { tourism }\end{array}$} & \multicolumn{4}{c|}{$\begin{array}{c}\text { hotel-based } \\
\text { tourism }\end{array}$} \\
\cline { 2 - 14 } & average & S.E. & average & S.E. & average & S.E. & \multicolumn{2}{|c|}{ average } & S.E. \\
\hline visits to historical sights & 3.265 & $\mathrm{a}$ & 0.085 & 3.794 & $\mathrm{c}$ & 0.097 & 3.294 & $\mathrm{ab}$ & 0.137 & 3.750 & $\mathrm{bc}$ & 0.094 \\
\hline visits to museums, galleries, etc. & 2.697 & $\mathrm{a}$ & 0.085 & 3.137 & $\mathrm{~b}$ & 0.096 & 3.000 & $\mathrm{ab}$ & 0.136 & 3.194 & $\mathrm{~b}$ & 0.094 \\
\hline shopping & 2.962 & $\mathrm{ab}$ & 0.089 & 2.618 & $\mathrm{a}$ & 0.101 & 3.353 & $\mathrm{~b}$ & 0.143 & 4.380 & $\mathrm{c}$ & 0.099 \\
\hline entertainment & 3.697 & $\mathrm{~b}$ & 0.081 & 3.186 & $\mathrm{ab}$ & 0.093 & 3.588 & $\mathrm{a}$ & 0.131 & 4.519 & $\mathrm{c}$ & 0.090 \\
\hline relaxation & 4.023 & $\mathrm{ab}$ & 0.077 & 3.882 & $\mathrm{a}$ & 0.088 & 3.137 & $\mathrm{c}$ & 0.124 & 4.269 & $\mathrm{~b}$ & 0.085 \\
\hline watching the nature & 4.379 & $\mathrm{a}$ & 0.078 & 4.176 & $\mathrm{a}$ & 0.089 & 2.549 & $\mathrm{~b}$ & 0.126 & 3.454 & $\mathrm{c}$ & 0.087 \\
\hline bicycle touring & 4.000 & $\mathrm{c}$ & 0.086 & 1.833 & $\mathrm{a}$ & 0.098 & 2.216 & $\mathrm{ab}$ & 0.139 & 2.306 & $\mathrm{~b}$ & 0.095 \\
\hline recreational sport activities & 3.962 & $\mathrm{~b}$ & 0.084 & 2.725 & $\mathrm{a}$ & 0.095 & 2.980 & $\mathrm{a}$ & 0.135 & 3.694 & $\mathrm{~b}$ & 0.092 \\
\hline hiking & 4.220 & $\mathrm{a}$ & 0.081 & 4.078 & $\mathrm{a}$ & 0.092 & 2.608 & $\mathrm{~b}$ & 0.131 & 3.157 & $\mathrm{c}$ & 0.090 \\
\hline
\end{tabular}

Tab. 1: Average values ( \pm mean error, S.E.) of the degree of participation in recreation activities for the respective identified segments of demand. The averages marked with the same letter do not significantly differ (Tukey's multiple range post-hoc test for unequal sample sizes, $p>0.05), N=393$

Note: the scale of measure employed, where $1=I$ don't go for this activity, ... $5=$ I do go especially for this activity.

The relative attractiveness was determined for the respective attractions within each segment (Tab. 2). Tower houses in the segment "hotel-based tourism oriented to entertainment and recreational activities" were labelled as the absolutely most attractive (Tab. 2). On the contrary, the absolutely least attractive places are identified as golf courses in the segment "traditional tourism oriented to the stay in nature and visit to historical monuments".

A very interesting finding struck us when regarding the attractiveness of the territory as a whole, according to the degree of the attractiveness of this territory for particular segments of demand. It is obvious from the comparison of the map outputs of the analysis that the degree of the perception of territory attractiveness by particular segments of demand has a fundamental spatial dimension. Such a comparison also confirms the necessity of including the visitors' preferences in the models of attractiveness (Bína, 2002), as well as the legitimacy of using the recreational activities for segmentation, which is important for the degree of attractiveness of particular preconditions of tourism development (Navrátil and Navrátilová, 2011).

It is impossible to detect more important differences in the spatial pattern of highly attractive places; they are concentrated in all cases particularly in the area of the Šmava Mountains. However, there is a cardinal difference in the degree of attractiveness of particular locations. For the first segment (Fig. 7), both tourist regions are attractive in a substantial part of their area (quartiles 50-75 and 75-100\%). The areas that are perceived as relatively unattractive include namely parts of the České Budějovice Basin, the Klatovy Depression and peripheral parts of the Třeboň Basin; a little bit more attractive is the part of the Písek area. South Bohemia and the Šumava Mountains as a whole are more attractive for the second segment of demand (Fig. 8). On the contrary, the third identified segment (Fig. 9) perceives South Bohemia and the Šumava Mts. area as mainly rather unattractive; the $25-50 \%$ quartile prevails in most of the surveyed area. Distinctively attractive areas could be found for this segment only in the mountainous part of the Sumava Mountains, the Lipno Reservoir area, alongside the Lužnice River and then the area of settlement centres. A similar character is seen in the distribution of attractive areas for the fourth segment of demand (Fig. 10), except for the difference that a larger part of both tourist regions belongs to areas of very low attractiveness. Highly attractive locations are for the case of the fourth segment of demand distributed rather regularly across the surveyed area with a light center in the area of the mountainous part of the Šumava Mountains.

From the spatial point of view (Fig. 11), the greatest number of highly attractive areas is concentrated in the area definable as the mountainous part of the Šumava Mountains. Highly attractive or rather attractive areas are concentrated also in the southern part of the territory: the Czech Canada and the Dačice area. However, some highly attractive areas are situated also in other parts of the territory. They are less frequented and are specifically related, above all, to the occurrence of watercourses and settlements. From the perspective of the overall surface, the South Bohemian Basins could be labelled as the less attractive areas (Fig. 11). 


\begin{tabular}{|c|c|c|c|c|}
\hline & $\begin{array}{l}\text { Modern outdoor } \\
\text { tourism }\end{array}$ & $\begin{array}{l}\text { Traditional } \\
\text { tourism oriented } \\
\text { to the stay in } \\
\text { nature and visit } \\
\text { to historical } \\
\text { monuments }\end{array}$ & $\begin{array}{c}\text { Rather passive } \\
\text { and non-engaged } \\
\text { tourism }\end{array}$ & $\begin{array}{c}\text { Hotel-based } \\
\text { tourism oriented } \\
\text { to entertainment } \\
\text { and recreational } \\
\text { activities }\end{array}$ \\
\hline landscape mostly covered by forests & 0.673 & 0.697 & 0.612 & 0.398 \\
\hline $\begin{array}{l}\text { landscape of mosaics of forests, } \\
\text { meadows and fields }\end{array}$ & 0.857 & 0.887 & 0.831 & 0.525 \\
\hline $\begin{array}{l}\text { landscape with predominant } \\
\text { agricultural land }\end{array}$ & 0.079 & 0.039 & 0.108 & 0.049 \\
\hline $\begin{array}{l}\text { landscape with frequent appearance } \\
\text { of ponds }\end{array}$ & 0.556 & 0.455 & 0.431 & 0.522 \\
\hline landscape of towns & 0.188 & 0.223 & 0.486 & 0.489 \\
\hline landscapes of highlands & 0.631 & 0.697 & 0.394 & 0.358 \\
\hline $\begin{array}{l}\text { landscapes with distinctive hillsides } \\
\text { and rocky mountain ridges }\end{array}$ & 0.656 & 0.647 & 0.426 & 0.360 \\
\hline landscape of high elevated plateaus & 0.456 & 0.426 & 0.257 & 0.268 \\
\hline landscapes of mountains & 0.481 & 0.434 & 0.286 & 0.322 \\
\hline landscapes of cirques & 0.497 & 0.415 & 0.290 & 0.320 \\
\hline landscapes of carved valleys & 0.458 & 0.384 & 0.269 & 0.292 \\
\hline landscapes of broad floodplains & 0.395 & 0.338 & 0.257 & 0.295 \\
\hline karst landscapes & 0.668 & 0.710 & 0.605 & 0.506 \\
\hline landscapes of flatlands & 0.329 & 0.282 & 0.326 & 0.284 \\
\hline rocks and crags & 0.540 & 0.580 & 0.452 & 0.365 \\
\hline peatbogs & 0.266 & 0.331 & 0.210 & 0.140 \\
\hline $\begin{array}{l}\text { meadow vegetation close } \\
\text { to the traditional farming }\end{array}$ & 0.295 & 0.308 & 0.257 & 0.159 \\
\hline rocks, crags & 0.540 & 0.541 & 0.405 & 0.324 \\
\hline occurrence of a rare animal & 0.429 & 0.345 & 0.265 & 0.305 \\
\hline occurrence of a rare plant & 0.295 & 0.261 & 0.257 & 0.198 \\
\hline cave & 0.589 & 0.631 & 0.677 & 0.763 \\
\hline spring with potable water & 0.404 & 0.308 & 0.317 & 0.251 \\
\hline spring with mineral water & 0.369 & 0.324 & 0.345 & 0.318 \\
\hline waterfall & 0.817 & 0.798 & 0.624 & 0.849 \\
\hline church & 0.211 & 0.290 & 0.277 & 0.272 \\
\hline monastery & 0.191 & 0.295 & 0.273 & 0.241 \\
\hline chapel & 0.132 & 0.166 & 0.202 & 0.203 \\
\hline Jewish monument & 0.167 & 0.217 & 0.269 & 0.232 \\
\hline tower house & 0.591 & 0.831 & 0.884 & 1.000 \\
\hline castle & 0.558 & 0.805 & 0.839 & 0.985 \\
\hline $\begin{array}{l}\text { remains of fortresses and fortified } \\
\text { settlements }\end{array}$ & 0.325 & 0.402 & 0.350 & 0.342 \\
\hline $\begin{array}{l}\text { ruins of tower houses } \\
\text { or other monuments }\end{array}$ & 0.512 & 0.663 & 0.624 & 0.623 \\
\hline memorial of an important person & 0.147 & 0.176 & 0.202 & 0.216 \\
\hline
\end{tabular}

Tab. 2: The relative degrees of attractiveness of the surveyed attractions for the respective identified segments 


\begin{tabular}{|c|c|c|c|c|}
\hline & $\begin{array}{l}\text { Modern outdoor } \\
\text { tourism }\end{array}$ & $\begin{array}{l}\text { Traditional } \\
\text { tourism oriented } \\
\text { to the stay in } \\
\text { nature and visit } \\
\text { to historical } \\
\text { monuments }\end{array}$ & $\begin{array}{c}\text { Rather passive } \\
\text { and non-engaged } \\
\text { tourism }\end{array}$ & $\begin{array}{c}\text { Hotel-based } \\
\text { tourism oriented } \\
\text { to entertainment } \\
\text { and recreational } \\
\text { activities }\end{array}$ \\
\hline Calvary chapels & 0.097 & 0.092 & 0.080 & 0.077 \\
\hline Calvary crosses & 0.077 & 0.061 & 0.083 & 0.051 \\
\hline conciliation crosses & 0.090 & 0.066 & 0.074 & 0.053 \\
\hline historically important cemetery & 0.145 & 0.186 & 0.158 & 0.185 \\
\hline museum & 0.351 & 0.436 & 0.514 & 0.536 \\
\hline open-air museum & 0.345 & 0.428 & 0.436 & 0.381 \\
\hline dilapidated villages & 0.151 & 0.147 & 0.136 & 0.136 \\
\hline gallery & 0.155 & 0.304 & 0.265 & 0.316 \\
\hline point of an important historical event & 0.247 & 0.301 & 0.308 & 0.292 \\
\hline $\begin{array}{l}\text { place where an important historic } \\
\text { person was living and/or creating }\end{array}$ & 0.158 & 0.257 & 0.217 & 0.249 \\
\hline important border stone & 0.123 & 0.121 & 0.151 & 0.097 \\
\hline monuments of popular architecture & 0.334 & 0.290 & 0.299 & 0.320 \\
\hline town historical buildings & 0.336 & 0.407 & 0.586 & 0.553 \\
\hline theatre & 0.227 & 0.282 & 0.360 & 0.495 \\
\hline observation and viewpoint & 0.601 & 0.605 & 0.503 & 0.594 \\
\hline historical factories & 0.160 & 0.113 & 0.195 & 0.114 \\
\hline historical mines and panning sites & 0.134 & 0.140 & 0.116 & 0.109 \\
\hline rural workrooms and storehouses & 0.162 & 0.163 & 0.171 & 0.112 \\
\hline water mills and iron-mills & 0.289 & 0.242 & 0.202 & 0.247 \\
\hline historical transport equipment & 0.125 & 0.154 & 0.124 & 0.146 \\
\hline water tanks and waterworks towers & 0.063 & 0.067 & 0.057 & 0.063 \\
\hline water dams & 0.431 & 0.295 & 0.410 & 0.374 \\
\hline $\begin{array}{l}\text { line fortification of the Czechoslovak } \\
\text { Republic }\end{array}$ & 0.117 & 0.121 & 0.133 & 0.059 \\
\hline offer of horse riding & 0.111 & 0.121 & 0.065 & 0.128 \\
\hline $\begin{array}{l}\text { public outdoor swimming pools and } \\
\text { bathing places }\end{array}$ & 0.519 & 0.336 & 0.663 & 0.790 \\
\hline places suitable for paddling & 0.316 & 0.159 & 0.277 & 0.309 \\
\hline Pistes & 0.322 & 0.142 & 0.544 & 0.386 \\
\hline golf courses & 0.018 & 0.000 & 0.061 & 0.125 \\
\hline tennis courts & 0.077 & 0.034 & 0.095 & 0.208 \\
\hline Spas & 0.302 & 0.322 & 0.405 & 0.525 \\
\hline zoological garden & 0.499 & 0.650 & 0.593 & 0.871 \\
\hline botanical garden and arboretum & 0.295 & 0.407 & 0.282 & 0.360 \\
\hline possibility of climbing & 0.170 & 0.039 & 0.063 & 0.078 \\
\hline observatories and planetariums & 0.228 & 0.288 & 0.142 & 0.282 \\
\hline possibility of recreational fishing & 0.053 & 0.022 & 0.028 & 0.022 \\
\hline
\end{tabular}

Tab. 2: continuing 

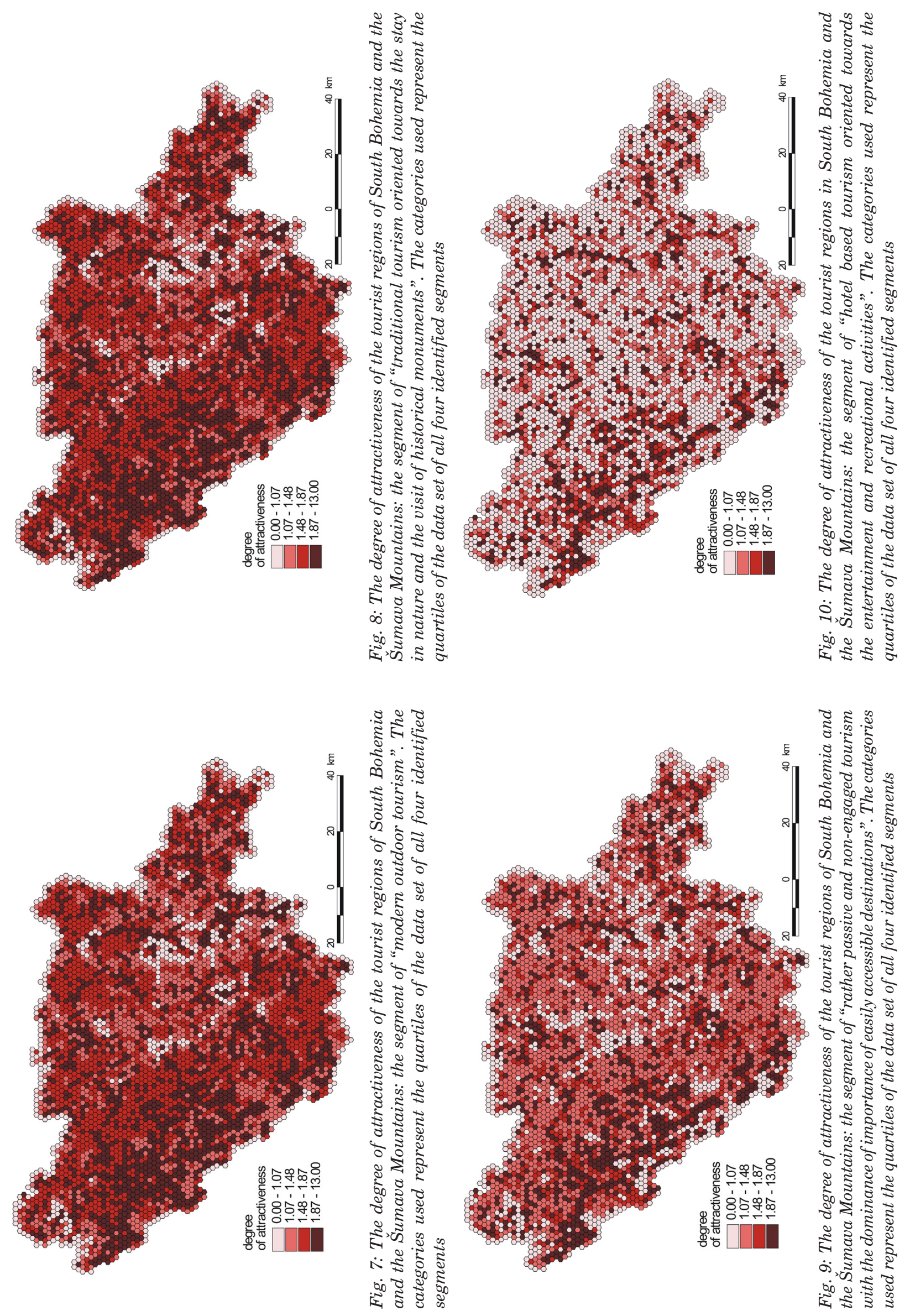

총ํำ

要

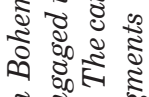

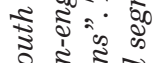

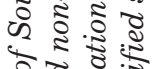

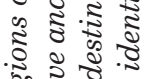
So.

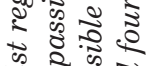

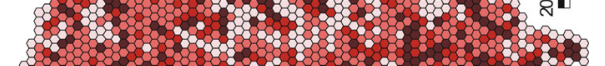

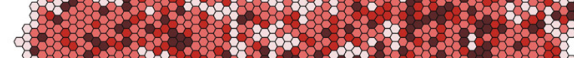

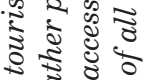
m m $8 \mathrm{~m}$ Hom H

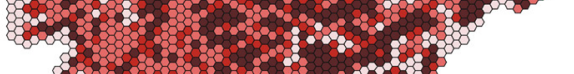

6.8.6.

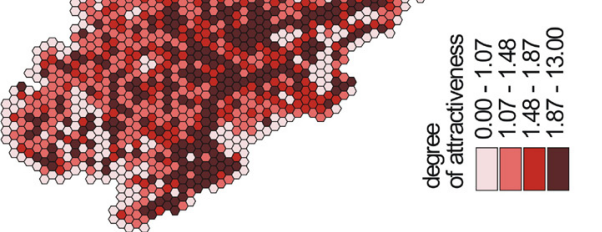

$\infty$ 竎

ईँ

ఫूँ

व. क्षे

น.

कू.

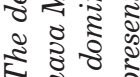

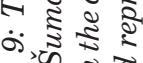

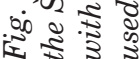




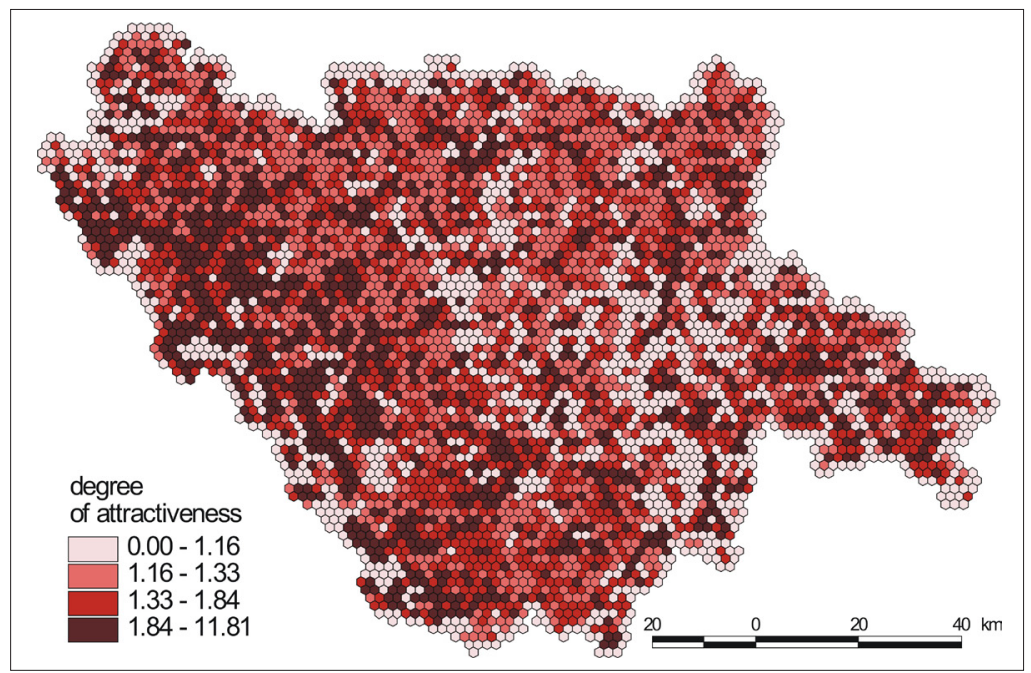

Fig. 11: Degree of total attractiveness of the tourist regions South Bohemia and Šumava Mts

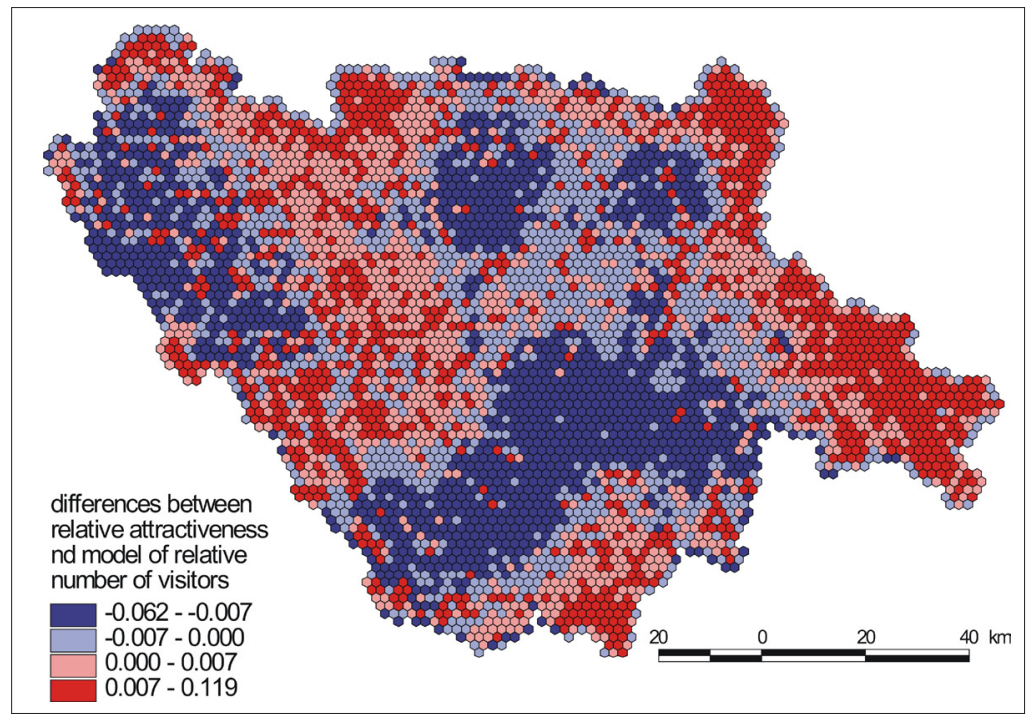

Fig. 12: Spatial identification of the development areas of tourism in the regions of South Bohemia and Šumava Mts., based on differences between the relative attractiveness and the model of relative attendance

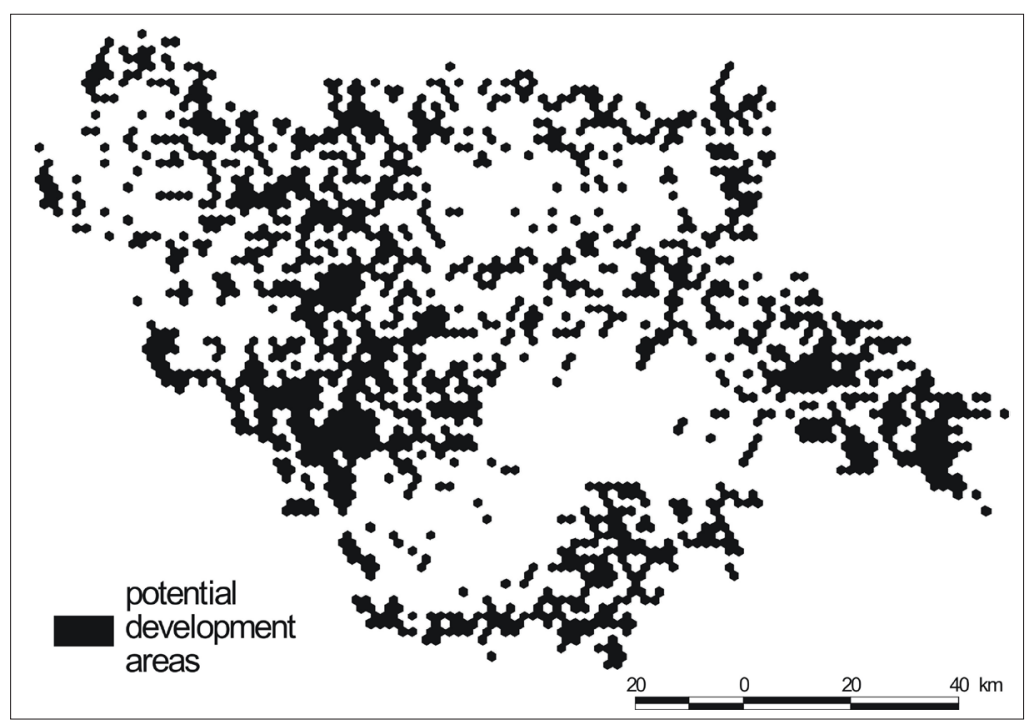

Fig. 13: Spatial identification of the development areas of tourism in the tourist regions of South Bohemia and Šumava Mts. based on the intersection of areas showing positive values of differences between the relative attractiveness and relative model number of visitors and attractive areas 
When comparing the attractiveness of the territory with the model number of its visitors, we can identify specific areas, which show a surplus of attractiveness, i.e. those where the relative surplus of attractiveness exists in relation to relative attendance.

Five spatial areas with lower development of tourism in the surveyed area can be identified in the spatial formulation (Fig. 12): those are part of the Šumava Mountains in the surroundings of Prachatice, Novohradské Hory Mts., Jindřichův Hradec and Dačice, the South Bohemian part of the area called the Czech Siberia, and the area of Blatná.

Primarily those parts of the surveyed areas could potentially become developed areas, which are, at the same time, of above-average attractiveness. However, the intersection of the above-average attractive areas with the areas showing a surplus of attractiveness against the model attendance (Fig. 13), identifies the more compact potentially developed areas only in the case of Jindřichův Hradec area, Dačice area and the part of the Šumava Mts. in the surroundings of Prachatice. In the Jindrichův Hradec area, it is primarily the hilly area element, followed in the south by another attractive part of Nová Bystřice and Staré Město, i.e. a substantial part of the area called the "Czech Canada". The developed parts of the Dačice area are the Dačice Depression and the south-east bordering areas of the Brtnice Upland.

The largest area that is attractive and at the same time shows an excess of the relative degree of attractiveness over the relative degree of the model attendance rate, is the southern part of the Prachatice area. Here the river basin of the upper Blanice R. and the valley of the Warm Vltava River, with the surrounding hillsides, represent the most compactly developed area. The area extends to the Boubín Forest in the north and up to the Knížecí Pláně (Fuerstenhut) with the apparent split of the land in the ridge part of the Šumava Mts. in the south. Another closed area of development is constituted by the surroundings of Volyně. This area is determined approximately by the Volyně-MaleniceČkyně-Čestice quadrangle. A larger number of developmental hexagons, but still not constituting a compact area, is situated in the area of the Šumava Foothills among the towns of Strakonice, Horažd'ovice and Sušice. Other areas can be detected from Fig. 13: the Blatná area, the Novohradské Hory Mts. and the Pacovská vrchovina Hilly Land to the east of Tábor.

What is also interesting is the comparison of areas with an attendance surplus. While the areas in both the south and the north are almost compact, the area of the "Mountainous Šumava" comprises, despite the high attendance in the entire territory, quite a high number of areas where the relative attractiveness surpasses the relative model attendance rate (Fig. 12, Fig. 13).

\section{Conclusions}

\section{Theoretical and methodological conclusions}

The assessment of the spatial distribution of tourists in the destination regions is problematic due to the lack of empirical data on the number of visitors to many tourist attractions. The proposed model of the spatial distribution of visitors is derived from the assumption that the tourists are accommodated during their stay in the model territory in some of the accommodation facilities. These accommodation facilities can then possibly to be understood as cores from which the visitors spread out to attractive localities in the region (Schoval, McKercher, Ng and Birenboim, 2011). It has already been demonstrated that accommodation facilities in the surveyed area are situated in localities considered in the literature as attractive (Navrátil et al., 2012).

Numerous approaches exist to modelling the attractiveness of a territory for tourism: for example, see the Czech and Slovak research papers recently summarized by Vystoupil, Holešinská, Kunc and Šauer, 2008, and Vystoupil and Kunc, 2009. Considering the fact that the impact of demand segment on the perception of the degree of attractiveness of the attractions is well known, this basic model (derived from the location of preconditions for the development of tourism - Mariot, 1983) was completed with the degree of attractiveness of the observed types of attractions for partial segments of demand. Those segments were determined based on interrogating the visitors in the surveyed tourist regions. The attractiveness of particular areas significantly differs among particular demand segments, thus affecting the total attractiveness of the surveyed territory.

The spatially varied location of the particular attractions made it possible to identify areas showing a surplus of attractiveness over the model demand. The results are related to the mean values of the observed indicators in the surveyed territory. They confirm the assumption of the existence of a territory with aboveaverage attractiveness but with values of a belowaverage visit rate in the surveyed area.

\section{Practical implications}

These conclusions are particularly useful when managing the number of visitors to the attractions and destinations, namely within the management of tourism in vulnerable areas when considering the objectives 
of regional development (Foret and Foretová, 2001; Foret and Klusáček, 2011; Macháček, 2004; Rumpel et al., 2011).

Obtaining knowledge of the spatial distribution of visitors is important for the management of destinations. That distribution is concentrated in the surveyed area into two main areas: the north-western Šumava Mts and the arch in the southeastern part of the territory, which is created by the mutually entwining zones of the Lipno Reservoir area, the Český Krumlov area, the České Budějovice area and the northern Třeboň area. The third area is the zone of the north with cores in the Písek-Orlík area and in Tábor. The attractiveness of the territory was assessed as well, based on the perception of attractiveness of all partial observed types of attractions by model respondents. The above-mentioned perception analysis confirmed a distinctive difference in the attractiveness of the territory for different types of visitors, who visit all the respective areas and meet one another at the attractions. The potential areas of development were located by the model in the Jindřichův Hradec area, the Dačice-Slavonice area and the Javornická vysočina Highland. The potential for development was detected especially for a larger part of the Prachatice area in the Šmava Mts.

\section{Limitations in using these research results}

The main limitation of the research results consists primarily in their relative foundation. The employed methodology is relative in its core: the results of the partial areas are in this treatise always related to the overall data of the whole area, so their validity is non-transferable in absolute data and not comparable with the outputs of other areas. Nevertheless, it is possible that they can be applied on various levels of the spatial measure. Possibilities of the extension of this study are obvious: enlargement of the surveyed territory to the level of the entire Czech Republic. Another problem of the model is the generalization of the homogeneity of the degree of attractiveness for all attractions of a given type (Bína, 2002). The model presented here is also limited only to the basic elements of the competitiveness of the destinations, which are the core sources and attractions as well as the basic attractions related to the previously-cited elements. The aim was to assess elements that are unambiguously spatially locatable. For that reason, the model of identification of the areas of development does not include other elements that are important for the competitiveness of destinations (Buhalis, 2000; Ritchie and Crouch, 2003).

\section{Acknowledgement}

This paper was compiled with the support from the Czech Science Foundation - GACR P404/12/0334 "Factors of visitors' relation to the ambience of attractions in vulnerable areas". The authors also express their gratitude to 19 students as data collection assistants and all those who participated likewise in the questionnaire surveys.

\section{References:}

AOPK ČR (2011). Ústřední seznam ochrany př́rody. [online]. [cit. 2011-11-15]. Available at: URL: <http://drusop.nature.cz/>

AOPK ČR (2012). Jednotná evidence speleologických objektů. [online] [cit. 2012-04-01]. Available at: URL: <http://jeso. nature.cz/>.

APLIN, G. (1983): Order-neighbour analysis. Norwich, Geo Books, 38 pp.

ATHAN, T., BLAZEK, R., CONTRERAS, G., DASSAU, O., DOBIAS, M., ERSTS, P. et al. (2011): Quantum GIS user guide, Version 1.7.0 'Wroclaw'. [online] [cit. 2011-10-20]. Avaible at: URL: <http://download.osgeo.org/qgis/doc/manual/qgis1.7.0_user_guide_en.pdf>

BARRY, J., PROOPS, J. (1999): Seeking sustainability discourses with Q methodology. Ecological Economics, Vol. 28, No. 3, p. 337-345.

BENTHIEN, B. (1997): Geographie der Erholung und des Tourismus. Gotha, Justus Perthes Verlag, 192 pp.

BÍNA, J. (2002): Hodnocení potenciálu cestovního ruchu v obcích České republiky. Urbanismus a územní rozvoj, Vol. 5, No. 1, p. $2-11$.

BUHALIS, D. (2000): Marketing the competitive destination in the future. Tourism Management, Vol. 21, No. 1, p. $97-116$.

CETKOVSKÝ, S., KLUSÁČEK, P., MARTINÁT, S., ZAPLETALOVÁ, J. (2007): Some aspects of cross-border cooperation in Euroregions of the Czech Republic: An example of the Šumava Region. Moravian Geographical Reports, Vol. 15, No. 1, p. 43-55.

ČRS (2003): Statistika úlovků 2002. CD-ROM, Dep.: Výbor územního svazu pro Severní Moravu a Slezsko ČRS, Ostrava.

DAWKINS, C. J. (2003): Regional development theory: Conceptual foundations, classic works, and recent developments. Journal of Planning Literature, Vol. 18, No. 2, p. 131-172.

DOODY, D., KEARNEY, P., BARRY, J., MOLES, R., O'REGAN, B. (2009): Evaluation of the Q-method as a method of public participation in the selection of sustainable development indicators. Ecological Indicators, Vol. 9, No. 6, p. 1129-1137. 
DWYER, L., FORSYTH, P., DWYER, W. (2010): Tourism economics and policy. Bristol, Channel View Publications, 776 pp. ECONOMIA (2002): Atlas pro volný čas. Praha, Economia,120 pp.

FORET, M., FORETOVÁ, V. (2001): Jak rozvíjet místní cestovní ruch. Praha, Grada, 180 pp.

FORET, M., KLUSÁČEK, P. (2011): The importance of the partnership and cooperation in the regional development exampled on Znojmo region. Acta Universitatis Agriculturae et Silviculturae Mendelianae Brunensis, Vol. 59, No. 4, p. 79-85.

GIBSON, C. (2008): Locating geographies of tourism. Progress in Human Geography, Vol. 32, No. 3, p. 407-422.

GOELDNER, C. R., RITCHIE, J. R. B. (2009). Tourism: Principles, practices, philosophies. New York, Wiley, 1092 pp.

GUNN, C. A. (1997): Vacationscape: Developing tourist areas. Washington, Taylor and Francis, 196 pp.

HALL, C. M., LEW, A. A. (2009): Understanding and managing tourism impacts: An integrated approach. Oxon, Routledge, 392 pp.

HALL, C. M., PAGE, S. (2009): Progress in tourism research: From the geography of tourism to geographies of tourism - A review. Tourism Management, Vol. 30, No. 1, p. 3-16.

HASHIMOTO, A. (2002): Tourism and sociocultural development issues. In R. Sharpley and D. J. Talfer, Tourism and development. Concepts and issues (pp. 202-230). Clevedon, Channel View Publications, 397 pp.

CHRISTOFAKIS, M. (2010): Strategic options for tourism impacts on local sustainability: A conceptual approach. Local Economy, Vol. 25, No. 7, p. 586-598.

CHYTRÁ, M., HANZELKA, P., KACEROVSKÝ, R. [eds.] (2010): Botanické zahrady a arboreta České republiky. Praha, Academia.

KITSON, M., MARTIN, R., TYLER, P. (2004): Regional competitiveness: An elusive yet key concept? Regional Studies, Vol. 38, No. 9, p. 991-999.

KOTLER, P., KELLER, K. L. (2007): Marketing management. Praha, Grada, 787 pp.

KŘÍŽ, H. (1985): Podzemní vody. In: Chábera, S. et al. [eds.], Jihočeská vlastivěda. Přírodní vědy. Neživá příroda (pp. 153166). České Budějovice: Jihočeské nakladatelství, 269 pp.

KUŠEN, E. (2010): A system of tourism attractions. Tourism - An International Interdisciplinary Journal, Vol. 58, No. 4, p. 409-424.

LÖW, J., NOVÁK, J. (2008). Typologické členění krajin České republiky. Urbanismus a územní rozvoj, 11(6), 19-23.

MACHÁČEK, J. (2004): Koncept místního rozvoje. In Grospič, J.: Úvod do regionálních věd a veřejné správy. Plzeň: Aleš Čeněk, p. 213-225

MARIOT, P. (1983): Geografia cestovného ruchu. Bratislava, Akadémia, 252 pp.

MIHALIČ, T. (2002): Tourism and economic development issuues. In Sharpley, R., Talfer, D. J. Tourism and development. Concepts and issues (pp. 81-111). Clevedon, Channel View Publications, 397 pp.

MOUTINHO, L. [eds.] (2000): Strategic management in tourism. Oxon, CABI Publishing, 349 pp.

NAVRÁTIL, J. (2004): Konflikty rekreačního rybolovu s životním prostředím z pohledu zástupců MO MRS. In V. Herber [eds.], Fyzickogeografický sborník 1 (p. 217-220). Brno: PřF MU \& ČGS.

NAVRÁTIL, J. (2008): Vodní komponenta krajiny v přírodně orientovaném venkovském cestovním ruchu na příkladu Třeboňska. Acta Universitatis Bohemiae Meridionales, Vol. 11, No. 1, p. 73-82.

NAVRÁTIL, J., PÍCHA, K., HŘEBCOVÁ, J. (2010): The importance of historical monuments for domestic tourists: The case of South-western Bohemia (Czech Republic). Moravian Geographical Reports, Vol. 18, No. 1, p. 45-61.

NAVRÁTIL, J., PÍCHA, K., RAJCHARD, J., NAVRÁTILOVÁ, J. (2011): Impact of visit on visitors ' perceptions of the environments of nature-based tourism sites. Tourism, Vol. 59, No. 1, p. 7-23.

NAVRÁTIL, J., NAVRÁTILOVÁ, J. (2011): Geografie pro cestovní ruch. České Budějovice, EF JU v ČB, 230 pp.

NAVRÁTIL, J., ŠVEC, R., PÍCHA, K., DOLEŽALOVÁ, H. (2012): The location of tourist accomodation facilities: A case study of the Šumava Mts. and South Bohemia tourist regions (Czech Republic). Moravian Geographical Reports, Vol. 20, No. 3, p. $50-63$.

NAVRÁTIL, J., PÍCHA, K., NAVRÁTILOVÁ, J. (2012): Satisfaction with visit to tourism attractions. Tourism, Vol. 60, No. 4, p. $411-430$.

NAVRÁTIL, J., PÍCHA, K., KNOTEK, J., KUČERA, T., NAVRÁTILOVÁ, J., RAJCHARD, J., WHITE BARAVALLE GILLIAM, V. L. (2013): The comparison of attractiveness of tourist sites for ecotourism and mass tourism: The case of waters in mountainous protected areas. Tourismos: an International Multidisciplinary Journal of Tourism, 8(1). (accepted)

NPÚ (2012). WMS/neverejne_sprava_wms (MapServer). [online] [2012-04-10]. Available at: URL: <http://mapy.npu.cz/ ArcGIS/rest/services/WMS/neverejne_sprava_wms/MapServer > 
POMPUROVÁ, K. (2011): Atraktívnost Slovenska pre vybraný segment návštěvníkov. E+M Ekonomie a Management, Vol. 14, No. 2, p. 137-150.

RAY, D. (2008): Development economics. In S. N. Durlauf \& L. E. Blume [eds.], The new Palgrave dictionary of economics. Palgrave Macmillan. [online] [cit. 2012-04-21]. Available at: URL: <http://www.dictionaryofeconomics.com/ article?id=pde2008_D000105>

REAL, E., ARCE, C., SABUCEDO, J. M. (2000): Classification of landscapes using quantitative and categorical data, and prediction of their scenic beauty in north-western Spain. Journal of Environmental Psychology, Vol. 20, No. 4, p. 355-373.

RITCHIE, J. R. B., CROUCH, G. I. (2003): The competitive destination: A sustainable tourism perspective. Oxon, CABI Publishing, $272 \mathrm{pp}$.

RUMPEL, P., BORUTA, T., SLACH, O., BEDNÁŘ, P., HAVRLANT, J. NOVÁK, D. W., PTÁČEK, P., ŽUFAN, P. (2011): Komplexní regionální marketing periferního rurálního regionu Jesenicko. Plzeň, Aleš Čeněk, 244 pp.

SHARPLEY, R. (2002). Tourism and development - A vehicle for evelopment? In Sharpley, R., Talfer, D. J.: Tourism and development. Concepts and issues (pp. 11-34). Clevedon, Channel View Publications, 397 pp.

SHOCart (2012): Turistická mapa. [online]. [cit. 2012-04-02]. Available at: URL: <http://www.mapy.cz>

SHOVAL, N., MCKERCHER, B., NG, E., BIRENBOIM, A. (2011): Hotel location and tourist activity in cities. Annals of Tourism Research, Vol. 38, No. 4, p. 1594-1612.

STATSOFT (2011): Electronic statistics textbook. StatSoft, Tulsa. [online]. [cit. 2011-10-12]. Available at: URL: < http:// www.statsoft.com/textbook/>

ŠVEC, R., NAVRÁTIL, J., PÍCHA, K., WHITE BARAVALLE GILLIAM, V.L. (2012) The Perception of the Quality of Accommodation Establishments' Product. DETUROPE. Central European journal of regional development and tourism. Vol. 4, No. 2, p. 4-21. ISSN 1821-2506

TELFER, D. J. (2002a): The evolution of tourism and development theory. In Sharpley, R., Talfer, D. J.: Tourism and development. Concepts and issues (pp. 35-80). Clevedon, Channel View Publications, 263 pp.

TELFER, D. J. (2002b): Tourism and regional development issues. In Sharpley, R., Talfer, D. J.: Tourism and development. Concepts and issues (p. 112-148). Clevedon, Channel View Publications, 263 pp.

TIMOTHY, D. J. (2002): Tourism and community development issues. In In Sharpley, R., Talfer, D. J.: Tourism and development. Concepts and issues (p. 149-164). Clevedon, Channel View Publications, 263 pp.

VEPŘEK, K. (2002): Hodnocení potenciálu cestovního ruchu a jeho využití v územních plánech VỨC. Urbanismus a územní rozvoj, Vol. 5, No. 3, p. 17-28.

VYSTOUPIL, J., HOLEŠINSKÁ, A., KUNC, J., ŠAUER, M. (2008): Teoreticko-metodologické přístupy k tvorbě rajonizace cestovního ruchu v České republice. Ekonomická revue cestovného ruchu, Vol. 41, No. 2, p. 105-117.

VYSTOUPIL, J. , KUNC, P. (2009): Geografický výzkum cestovního ruchu v ČR v letech 1950-2008. In: Halás, M., Klapka, P., Szczyrba, Z. [eds.], Geographia Moravica 1: Sborník prací k šedesátinám doc. RNDr. Václava Touška, CSc., p. 103-119, Univerzita Palackého v Olomouci, Olomouc.

VYSTOUPIL, J., HOLEŠINSKÁ, A., KUNC, J., MARYÁŠ, J., SEIDENGLANZ, D., ŠAUER, M., TONEV, P. et al. (2006): Atlas cestovního ruchu České republiky. Praha: Ministerstvo pro místní rozvoj, 157 pp.

WILLIAMS, S. (1998): Tourism geography. London, Routledge, 212 pp.

WWW.ROPIKY.NET (1999-2012). Mapa Československého opevnění. [online]. [cit. 2012-01-01]. Available at: URL: <www. world/tourism.org>

\section{Author's adresses:}

RNDr. Josef NAVRÁTIL, Ph.D.

Department of Economics, Faculty of Economics, University of South Bohemia in České Budějovice

Studentská 13, 37005 České Budějovice, Czech Republic

e-mail:josefnav@gmail.com

Ing. Kamil PÍCHA, Ph.D.

Department of Trade and Tourism, Faculty of Economics, University of South Bohemia in České Budějovice Studentská 13, 37005 České Budějovice, Czech Republic

e-mail: kpicha@ef.jcu.cz 
Mgr. Stanislav MARTINÁT

Department of Environmental Geography, Institute of Geonics, Academy of Sciences,v. v. i.

Drobného 28, 60200 Brno, Czech Republic

e-mail:martinat@geonika.cz

JUDr. et Mgr. Jaroslav KNOTEK, Ph.D.

Department of Applied and Landscape Ecology, Faculty of Agronomy, Mendel University in Brno

Zemědělská 1, 61300 Brno, Czech Republic.

e-mail:jarda.knotek@uake.cz

RNDr. Tomáš KUČERA, Ph.D.

Department of Ecosystem Biology, Faculty of Science, University of South Bohemia in České Budějovice Branišovská 31, 37005 České Budějovice, Czech Republic

e-mail: kucert00@prf.jcu.cz

RNDr. Zuzana BALOUNOVÁ, Ph.D.

Department of Biological Studies, Faculty of Agriculture, University of South Bohemia in České Budějovice Studentská 13, 37005 České Budějovice, Czech Republic

e-mail:baloun@zf.jcu.cz

Vivian L. WHITE BARAVALLE GILLIAM (MA)

The Institute of Technology and Business in České Budějovice

Okružní 517/10, 370 01, České Budějovice, Czech Republic

e-mail:vivian@mail.vstecb.cz

Ing. Roman ŠVEC

Department of Trade and Tourism, Faculty of Economics, University of South Bohemia in České Budějovice Studentská 13, 37005 České Budějovice, Czech Republic

e-mail: rsvec@ef.jcu.cz

doc. RNDr. Ing. Josef RAJCHARD, Ph.D.

Department of Biological Studies, Faculty of Agriculture, University of South Bohemia in České Budějovice Studentská 13, 37005 České Budějovice, Czech Republic

e-mail: rajchard@zf.jcu.cz

Initial submission 20 June 2012, final acceptance 15 March, 2013

Please cite this article as:

NAVRÁTIL, J., PÍCHA, K., MARTINÁT, S., KNOTEK, J., KUČERA, T., BALOUNOVÁ, Z., WHITE BARAVALLE GILLIAM, V. L., ŠVEC, R., RAJCHARD, J. (2013): The Model of Identification of the Tourism Development Areas: A Case Study of the Šumava Mts. and South Bohemia Tourist Regions (Czech Republic). Moravian Geographical Reports, Vol. 21, No. 1, p. 25-40. 